Editorial

\title{
Paper Withdrawn by the Authors before the Issue Release
}

\section{Shu-Kun Lin}

MDPI AG, Postfach, CH-4005 Basel, Switzerland; Office: Kandererstrasse 25, 4057 Basel, Switzerland; E-Mail: lin@mdpi.com

Received: 17 December 2012 / Accepted: 17 December 2012 / Published: 17 December 2012

The following paper: "Jung, S.; Kim, J.H.; Kim, S. Bloom Filter-Based Advanced Traceback Scheme in Wireless Sensor Networks. Sensors 2012, 12, 16250-16261." has been withdrawn at the request of the authors before the issue release of Sensors Volume 12, Issue 12. We apologize for any inconvenience this may cause.

(C) 2012 by the authors; licensee MDPI, Basel, Switzerland. This article is an open access article distributed under the terms and conditions of the Creative Commons Attribution license (http://creativecommons.org/licenses/by/3.0/). 